\title{
Interactive comment on "Comment on "Shear wave reflection seismic yields subsurface dissolution and subrosion patterns: application to the Ghor Al-Haditha sinkhole site, Dead Sea, Jordan" by Polom et al. (2018)" by Michael Ezersky et al.
}

Michael Ezersky et al.

mikhailez@hotmail.com

Received and published: 4 December 2019

The comment was uploaded in the form of a supplement:

https://www.solid-earth-discuss.net/se-2019-132/se-2019-132-AC4-supplement.pdf 